\title{
Formation of Special Legal Regime of Ethnic Crime Prevention in Context of Forced Migration
}

\author{
Jacek Zieliński, Irina Pikuleva ${ }^{1}$ \\ Siedlce University of Natural Sciences and Humanities, \\ Social Sciences and Security Institute, Poland \\ uczelniajz@tlen.pl \\ ${ }^{1}$ Siberian Federal University, Law Institute, Russia
}

\section{Abstract}

Some aspects of the present issue of forced migration have been analysed in the article. The Authors note that the current geopolitical and economic reality necessitates modernisation of the approach to the detection, prevention and counteraction to ethnic crime. Taking into consideration the significance of the problem, the Authors suggest reference to the migrants' ethnic criminal activity in the framework of a special legal regime. It means that all public relations connected with the detection, prevention and counteraction to ethnic crime and other legal measures should be evaluated not only from the perspective of statutory regulation, but also in the context of real practice in this area. That allows for more realistic approach to the legal regime. The Authors give some directions of the statutory regulation improvement in the field of forced migration: strengthening of control over migration processes, suppression of ethnic enclaves' formation in cities, special control over internal environment of migrants' societies in order to prevent extremist views.

Keywords: migration, forced migration, ethnic crime, refugee, migrant, special legal regime.

\section{Introduction}

At the present stage of the development of public relations the questions of crime and its prevention become essential for the formation and guarantee of favourable conditions of community life of different population groups, nations and ethnic 
Jacek Zieliński, Irina Pikuleva. Formation of a special legal regime of ethnic crime prevention in the context of forced migration

groups. Upon the investigation of this problem, at present two factors deserve attention: the multinational nature of the Russian Federation, and the intensification of migratory flows to the territory of the Russian Federation in recent years that was caused by the military and political events in the south-east Ukraine [10], escalation of armed conflict in the Middle East, etc. The problem of ethnic crime and, especially, its manifestation in different regions gains significance; that is why it should be analysed not only in legal aspect, but in legal and factual aspects, in unity of reflection of the normative and real components of the pointed social life branch.

The aim of the research consists of searching for such legal instrument which will be able to optimise the existing conditions of legal situation in the sphere of ethnic crime by forced migrants. Investigation of not only legal frameworks, which carry a set of legal measures that have been recognised by the legislator for some reasons, but also analysis of the actual practice and existing relations are necessary for the solution of the concerned problem. It appears that the development of such approach will allow to simulate the most favourable and effective legal policy in the sphere of ethnic crime in conditions of forced migration.

Methodological basis of the investigation includes the dialectical method of scientific cognition, involving the study of phenomena and processes in their interconnection, interdependence and development. In the framework of this method, such techniques as analysis, synthesis, induction, deduction, ascent from the abstract to the concrete, comparison, analogy, abstraction, etc. have been used. In the capacity of the methods of obtaining categories "legal regime" and "special legal regime" contemporary achievements of the activity theory, interaction theory, factors' theory, situational approach were employed.

Empirical basis of the research consists of the Russian legal acts, monitoring data, statistical information, periodicals and other materials.

\section{Discussion}

First of all, we would like to refer to the category of "the phenomenon of ethnic crime" [12, 88], under which it is understood illegal activity, "organised by criminal groups established in the community of the same nationalities or the same related ethnics, languages, cultures, traditions and customs territories of origin or residence" [6, 206], aimed at committing various types of crimes by virtue of following the traditions of ethnic antisocial expressing pattern of behaviour of the group [16, 26].

From this definition, the main feature of ethnic crime can be pointed out: tying in to a specific ethnic community. Therefore, determining the degree of social danger, the prevalence and intensity of such crime is necessary in each specific region of migration on the assumption of the affiliation of the perpetrators to a particular ethnic group, taking into account social activity-regulating properties. For this reason, it seems that a realistic approach to understanding legal regimes (regional legal regimes) [12, 160-162] 
Jacek Zieliński, Irina Pikuleva. Formation of a special legal regime of ethnic crime prevention in the context of forced migration

is possible upon comprehensive and accurate characterisation of the existing situation in various regions of Russia not only from the formal legal position, but also in terms of exiting features that serve practical orientation of such understanding.

Traditional (normative) approach to understanding legal regimes as a special order of legal regulation of a particular area of public relations, consisting of a set of legal measures and their different specific combinations, allows to determine a regulatory framework for the regulation of a particular field of public relations. That is why it is limited by formal and declarative laws of social processes that are not consistent with the existing realities of legal life.

Legal regime (as a phenomenon), in realistic approach, is not stranded in the sphere of "possible" only, it also refers to the actual legal life. As a category, legal regime in this understanding reflects the real state of the situation and the importance of existing legal institutions, demonstrating how the state is represented by the legislator, and other lawmaking bodies establish the balance of interests of participants of public relations in various spheres of legal life, priorities of certain interests to the others [9, 17-18], not only in the norms of law, but also in their practical action. A realistic interpretation reflects the actual state of legal practice, which makes the selection of legal regimes in different scales possible.

As for the problematic of counteraction of ethnic crime at a national level: legal category of "regional legal regime" gains a fundamental importance because it indicates the actual, practical features of the "ethnic element" in different regions of the Russian Federation. The normative understanding of legal regimes is powerless in the explanation of the differences in the activities of ethnic criminal groups in different regions, specialisations of such kinds of crime. It is possible to highlight a number of criteria of differentiation of regional ethnic crime's legal regimes. So, in the Irkutsk region and the Republic of Buryatia (Buryats are the indigenous population) predominant crimes are related to manufacture, production, marketing of drugs.

The reasons are:

1) alcoholism, caused by physiological population (medical) criterion - peculiar to Asians' lack of the enzyme alcohol dehydrogenase, which allows the human body to counteract habits [13,89-90];

2) living conditions of these regions of Russia are represented extremely unfavourably that give impulse for the development of "hempen industry" (especially in Kyakhtinsky, Dzhidinsky and Selenga regions of Buryatia) [13, 89-90], etc.

In the area of North Caucasus the problem of ethnic crime is very topical. Tribal and clan organisation of the Caucasian societies, mentality peculiarities, traditional psychology of the Caucasian peoples, belonging to Islamic civilisation, traditional worldview, etc. [1, 65-74] - the primary criteria predetermining criminal "climate" in the North Caucasus region which directly contribute to and encourage the development of crime in these regions of Russia. 
Jacek Zieliński, Irina Pikuleva. Formation of a special legal regime of ethnic crime prevention in the context of forced migration

Examples of Buryat and Caucasian ethnic crime demonstrate a number of factors (criteria) of a legal regime that are not fit into the framework of the normative understanding (limited by "a set of legal measures") [7, 8]. However, realistic approach allows to reflect the characteristics of the actual situation of a particular region.

The above listed criteria also provide evidence of the imperfection of the "regulatory element" of regional legal regime against ethnic crime: the unsettled state of the respective spheres of social relations (normative obstacle-space [11, 6-12], indicating adverse regional legal regime), in other words, the gap in federal legislation regarding the regulation of national and ethnic relations directly implies inefficiency and low level of the law-making process in the regions.

The process of creating legal frameworks in the subjects of the Russian Federation is largely hampered by

"the uncertainty of the law-making competence of regional legislative bodies, and most of the Russian Federation in the field of regulation and protection of the rights of national and ethnic communities. In accordance with the provisions of Art. 72 of the Constitution of the Russian Federation [2], the protection of rights of national minorities refers to subjects of joint jurisdiction of the Federation and its subjects. On this subject there is still no strict allocation of powers and responsibilities between the Russian Federation and the subjects that entails duplication, competition and often one-sided expansion of the powers of the subject." $[8,65-71]$

As can be seen from the above, the usage of the realistic approach to the theory of legal regimes allows to define "criminal" climate of the region and to formulate specific recommendations for improving the regional legal regime against ethnic crime in order to ensure security and create the most favourable conditions for all citizens (for example, development of regional policy in the field of general and special prevention of ethnic gangs, etc.). In other words, the category of "legal regime" in the traditional sense is not fulfilling its primary function of a methodological tool to measure changes in the mechanism of legal regulation, fixing static public relations anchored in normative legal acts and other formal sources of law. The notion of "regional legal regime" in realistic understanding poses as informative; political and legal instrument as a measurement of the legal climate of regional development and its improvement in regional legal policy.

Returning to the concerned problematic of forced migration, it should be noted that at the present the process of forced migration has become a natural scale (both, in Russia and Europe), which makes becoming the adaptation and implementation of migrants in new locations difficult:

"The desired outcome of naturalisation is a solution of demographic problems, enhancing cultural heritage and economic well-being. But, in practice, the balance of interests of indigenous and "new" citizens is not always observed." $[15,160]$

It is obvious that uncontrolled and illegal migration flows have a negative impact on national legal order. 
Jacek Zieliński, Irina Pikuleva. Formation of a special legal regime of ethnic crime prevention in the context of forced migration

One of the primary consequences of migration is the growth of ethnic crime by relevant migrant flows, which, as can be seen from the examples mentioned above, depends not only on their own cultural and traditional characteristics of migrant background, but also on their social and economic situation in the country:

\begin{abstract}
"Firstly, the major part of migrants are young able-bodied men at the age of 18-40, who, on the one hand, do not lack a certain desire to enhance their well-being (just move to other countries and regions in search for work and "better life"), but, on the other hand, most of them do not have a high level of education and skills. In host societies migrants initially occupy the lowest rungs of social hierarchy, and the satisfaction of their ambitions depends on the increase of their material wellbeing. Secondly, a significant part of migrants arrives at the host countries from the more economically backward and radically different in cultural terms states and regions." [3]
\end{abstract}

That is why the social position of migrants should be taken into account and reflected in the current system of legal regulation.

It seems that the optimisation of the pointed problem requires the usage of the category of "legal regime" in the realistic approach to understand what can be applied to the research of the area of public relations of ethnic crime and criminality of migrants. As practice shows, crimes committed by certain ethnic groups and migrants are characterised by a distinct mechanism of criminal behaviour, the object of attacks, etc. That is why it cannot be taken into account in the process of formation of public policy and legal counteraction and prevention of crimes. Moreover, in the conditions of activation of migration processes it is necessary to talk about a special legal regime to prevent ethnic crime by migrants.

\title{
Results
}

As for the content-related part of special legal regimes, some main directions of improvement of ethnic crime sphere have to be pointed out [3].

First, strengthening of control over migration processes. Some activities in this direction have already been implemented. For example, the Federal Law No. 74-FZ [4] was amended: foreign citizens must prove the Russian language skills, knowledge of Russian history and the constitutional foundations of the Russian Federation, for example, to obtain a work permit. However, in practice, the existing regulation is not enough. For example, it is proposed to preserve and enhance the regime of restrictions of

"the usage of foreign workers and professionals in the region in general and specific enterprises or individual entrepreneurs. Herewith, if in the previous year the enterprise has attracted foreigners, but inspections were recorded violations of migration or labour legislations, it is forbidden for this enterprise to hire foreign workers and professionals for 2 years." [14] 
Jacek Zieliński, Irina Pikuleva. Formation of a special legal regime of ethnic crime prevention in the context of forced migration

Second, local fight and prevention of

"the possibility of the emergence of ethnic enclaves in the major cities. Many of the problems of the European cities, including Paris and Marseilles, were caused by the fact that on their territories were real "ghettos" inhabited by immigrants from the Asian and African countries. So, in Paris area Gut d'Or was popularly nicknamed as "Little Africa", because the main population makes Senegalese, Congolese and other immigrants from the African continent. In Marseille about $50 \%$ of the population are migrants from North Africa, occupying the entire areas of the city where the police do not go risking only as large and well-armed units." [3]

The concentration of a large number of migrants prevents socialisation of migrants and their integration into a new social environment.

Third, special attention should be paid to the "internal state" of migrant environments in terms of their social, political and religious activities:

"There are many examples of initiation of extremist organisations that were supported by the migrants for terrorist organisations operating in the migrants' home country. In this situation, administrative and law enforcement agencies should not work with the formal leaders of national and cultural organisations, many of which do not have any real influence on the migrants. In any case, the law enforcement bodies and special services need to intensify work in the direction of internal state of migrant environments, but it requires the creation of a specific regulatory framework: the liberal society, including the media and the scientific community, human rights activists, politicians, having a definite impact on lawmakers and even political power, can block the adoption of real bills aimed at regulating the migration policy and the fight against ethnic crime." [3]

\section{Conclusion}

To sum up, we have listed only some possible measures aimed at prevention of ethnic crime by migrants. In the framework of the category of special legal regime further improvement of migration policy in order to insure national security of the state is necessary, that is dictated by the existing realities of growth of risk factors.

\section{Īpaša tiesiskā režìma veidošana etniskās noziedzības novēršanai piespiedu migrācijas kontekstā}

\section{Kopsavilkums}

Rakstā tiek analizēti daži piespiedu migrācijas aspekti. Autori atzīmē, ka pašreizējā geopolitiskā un ekonomiskā realitāte prasa modernizētu pieeju, lai atklātu, novērstu un apkarotu etnisko noziedzību. N̦emot vērā problēmas nozīmīgumu, autori 
Jacek Zieliński, Irina Pikuleva. Formation of a special legal regime of ethnic crime prevention in the context of forced migration

iesaka īpašu tiesisko režīmu attiecỉbā uz migrantu etnisko noziedzīgo darbību. Tas nozīmē, ka visas sabiedriskās attiecības, kas saistītas, lai atklātu, novērstu un apkarotu etnisko noziedzību, jāizvērtē ne tikai no tiesiskā regulējuma, bet arī saistībā ar reālo praksi šajā jomā. Tas piel̦auj reālistiskāku pieeju īpašam tiesiskajam režīmam. Autori sniedz dažus ieteikumus tiesiskā regulējuma uzlabošanai piespiedu migrācijas jomā: stiprināt kontroli pār migrācijas procesiem, uzraudzìt etnisko anklāvu veidošanos pilsētās, veikt īpašu kontroli pār migrantu sabiedrības iekšējo vidi, lai novērstu ekstrēmistiskus viedokḷus.

Atslēgvārdi: migrācija, piespiedu migrācija, etniskā noziedzība, bēg̣̣i, migranti, ìpašs tiesiskais režìms.

\section{References}

1. Anzhirov, I. V. The influence of the clannish form of the formation of traditional societies of North Caucasus and Transcaucasus to the organization of ethnic crime in Russia. Theory and Practice of Social Development. 2010. 1, 65-74.

2. Constitution of the Russian Federation (12 Dec. 1993 г.). Legislation Bulletin of the Russian Federation. 2009, 4, 445.

3. Ethnic crime - danger of the national safety of Russia and other countries. Available from: www.liveinternet.ru/users/2503040/post349000151 [accessed on 25.02.2016].

4. Federal statute "Concerning the Introduction of Amendments to the Federal statute "Concerning the Legal Status of Foreign Citizens in the Russian Federation"” No. 74-FZ. Legislation Bulletin of the Russian Federation. 2014, 16, 1831.

5. Federal statute "Concerning the Legal Status of Foreign Citizens in the Russian Federation" No. 115-Ф3. Legislation Bulletin of the Russian Federation. 2002, 30, 3032.

6. Kasaev, I. H. Ethnic crime in Russia: criminological aspect. Legal Culture. 2011, 1, 206.

7. Kosak, A. V., Malko, A. V. The foundations of the theory of legal regimes. In: Legal Regimes: General-theoretical and Branch Aspects: Monograph. A. V. Malko, I. S. Barzilova. Moscow, 2012, 8.

8. Kuzmina, N. V. Negative legal factors in the system of determinants of ethnic crime. Bulletin of Volgograd Academy of Interior Ministry of Russia. 2013, 3, 65-71.

9. Matuzov, N. I., Malko, A. V. Legal regimes: questions of theory and practice. Jurisprudence. 1996, 1, 17-18.

10. Migrants: How many Ukrainian migrants are in Russia. Available from: http://www.migration-patent.ru/index/razdel3/skolko-ukrainskih-bezhencev-v-rossii [accessed on 25.02.2016].

11. Panchenko, V. Yu., Petrov, A. A. Classification of legal obstacles in realization of rights and legitimate interests. Law and State: theory and practice. 2013, 9, 6-12.

12. Panchenko, V. Yu., Pikuleva, I. V. Regional legal regime of rendering free legal aid. Historical, Philosophical, Political and Legal Sciences, Culturology and Art History. Questions of theory and practice. 2014, 10, 160-162.

13. Rabdanova, E. To the question of the phenomenon of ethnic crime. Siberian Legal Bulletin. 2003, 3, 89-90. 
Jacek Zieliński, Irina Pikuleva. Formation of a special legal regime of ethnic crime prevention in the context of forced migration

14. Strengthening of migration control and force in Russia. Russian Public Initiative. Available from: www.roi.ru/4976 (accessed on 26.02.2016).

15. Voloh, V. A. Forced migration in Europe: state, problems, ways of optimization of the optimization of administration and migration legislation in Russia. Power. 2016. 1, 160.

16. Zyukov, A. M. Criminological characteristics of the crimes, committed by the representatives from different ethnic groups: dissertation. Ryazan, 2005, 26. 